\title{
PERANAN DUKUNGAN SOSIAL DALAM MENCEGAH KEKERASAN DALAM PACARAN: STUDI KORELASI PADA REMAJA DI JAKARTA
}

\author{
Ainul Mardiah ${ }^{1 a}$, \\ Dwi Puspita Satriana ${ }^{a}$, \\ Elida Syahriati ${ }^{b}$ \\ ${ }^{a}$ Fakultas Psikologi \\ Universitas Mercu Buana \\ Jl. Meruya Selatan No1 \\ Jakarta Barat 11650, Indonesia \\ ${ }^{b}$ Fakultas Psikologi \\ Universitas Syiah Kuala \\ Jl. Teuku Nyak Arief, Darussalam \\ Kota Banda Aceh 23111, Indonesia \\ 'e-mail:ainulmardiahdjalil@gmail.com
}

\begin{abstract}
The present study aims to examine the influence of social supports (i.e. family, friends, and significant others) on dating violence in adolescents. The measuring instruments used were Multidimential Scale of Perceived Social Support and Conflict Adolescent Dating Relationship Inventory. In the present study 400 adolescents participated with the age range of 15 to 18 years old, whereas 305 (76.3\%) are female and 95 (23.8\%) are male. The result from regression analysis revealed that family support is important in preventing dating violence in adolescent. On the contrary, social support from friends and significant others do not contribute in preventing dating violence. Result, limitation, and suggestion are discussed.
\end{abstract}

Keywords: social support; dating violence; adolescence.

Abstrak - Penelitian ini dilakukan untuk melihat gambaran mengenai hubungan antara dukungan sosial (keluarga, teman dan orang terdekat) terhadap perilaku kekerasan dalam berpacaran pada remaja. Alat ukur yang digunakan dalam penelitian ini adalah Multidimential Scale of Perceived Social Support dan Conflict Adolescent Dating Relationship Inventory. Partisipan dalam penelitian ini adalah 400 remaja yang berusia 15-18 tahun, yang terdiri dari 305 remaja perempuan (76.3\%) dan 95 remaja laki-laki (23.8\%). Dari hasil uji regresi didapatkan bahwa dukungan keluarga berperan penting dalam mencegah tindak kekerasan pada remaja di Jakarta. Namun tidak dengan dukungan sosial dan significant others. Kesimpulan, limitasi dan saran didiskusikan lebih lanjut.

Kata Kunci: dukungan sosial; kekerasan dalam pacaran; remaja. 


\section{PENDAHULUAN}

Kekerasan dalam pacaran pada remaja semakin kerap terjadi belakangan ini. Peranan lingkungan sosial seperti keluarga dan teman sebaya memainkan peranan penting dalam mencegah tindak kekerasan dalam berpacaran. Hasil penelitian mengenai dukungan sosial terhadap kekerasan berpacaran sangatlah beragam. Penelitian Wall (2009) menjelaskan bahwa kedeketan orangtua, khususnya ibu, memiliki pengaruh yang sangat penting pada perkembangan harga diri anak remajanya sebagai pembentukan dasar seorang anak. Hal ini mempengaruhi pandangan-pandangan tentang hubungan kekerasan. Pemantauan orangtua muncul sebagai faktor pelindung untuk mengurangi korban dan agresi relasional kekerasan dalam pacaran.

Namun dalam penelitian Richards, Branch, dan Ray (2014), telah dibuktikan bahwa dukungan teman sebaya berhubungan erat dan berpengaruh lebih besar untuk menurunkan tingkat kekerasan dalam pacaran pada remaja dibandingkan dengan dukungan dari orangtua. Studi sebelumnya menunjukkan bahwa dukungan sosial berpengaruh secara berbeda untuk remaja laki-laki dan perempuan. Tetapi dibandingkan anak laki-laki, anak perempuan secara signifikan lebih mungkin untuk mendapatkan dukungan sosial. Remaja laki-laki dan perempuan dihubungkan memiliki harapan yang berbeda tentang komitmen, kesetiaan, dan pemahaman dari teman-teman. Orangtua tetap memiliki pengaruh pada anak selama masa remaja, namun pengaruh teman lebih dominan dibandingkan orangtua. Hal ini dikarenakan anak lebih menghargai nilai-nilai persahabatan. Penelitian Leadbeater, Banister, Ellis, dan Yeung (2008) menjelaskan remaja mungkin belajar tentang hubungan yang romantis dengan mengamati dan merefleksi atas perilaku orang lain.

Dari paparan di atas ditemukan bahwa dukungan dari keluarga dan teman berpengaruh dan berkorelasi terhadap kecenderungan seseorang untuk melakukan atau menjadi korban kekerasan dalam berpacaran. Sejauh yang peneliti ketahui, belum ada penelitian yang menunjukkan bagaimana hubungan orang yang spesial terhadap kecenderungan kekerasan dalam berpacaran. Oleh sebab itu, peneliti ingin mengeksplorasi lebih jauh mengenai dukungan dari orang yang spesial terhadap kecenderungan kekerasan dalam berpacaran, baik itu dari sisi korban maupun pelaku.

\section{Kekerasan dalam Pacaran}

Kekerasan dalam pacaran adalah tindakan emosional, psikologis, fisik, dan seksual yang kasar. Perilaku kasar ini dapat digunakan, dengan atau tanpa niat atau pemahaman dalam hubungan 
pacaran yang melibatkan setidaknya satu remaja (Payne, Ward, Miller, \& Vasquez, 2013). Kekerasan dalam pacaran ada berbagai jenis, yaitu fisik, emosional, verbal, psikologis, dan lain-lain. Dalam penelitian Davis (2008), definisi pada kekerasan fisik yaitu setiap perilaku kekerasan yang bertujuan untuk mengendalikan atau menyakiti pasangan dan termasuk pula ancaman dan tindakan intimidasi, seperti memukul yang disengaja, menampar, atau secara fisik disakiti oleh pacar lelaki atau pacar perempuannya. Kekerasan atau pelecehan verbal biasanya yang menjadi penanda bahwa hubungan memiliki potensi untuk menjadi kekerasan fisik dan beberapa remaja dapat salah mengartikan agresi atau pelecehan verbal sebagai bentuk cinta (Wall, 2009). Sedangkan kekerasan emosional lebih dirasakan atau berdampak pada perasaan sakit hati, tertekan, marah, perasaan terkekang, minder, dan perasaan lain-lain yang tidak nyaman (Nurakhmi \& Astuti, 2008). Ketiganya juga sering disebut perilaku kekerasan dalam pacaran. Namun perilaku kekerasan dalam pacaran tidak hanya mencakup pelecehan fisik saja, tapi juga pelecehan seksual dan pelecehan psikologis (Lamm, 2010).

Kekerasan dalam pacaran pada remaja memiliki dampak negatif dalam berbagai aspek yaitu fisik, psikologis, dan relasional. Dampak fisik tergantung pada jenis kekerasan yang dilakukan. Lukaluka yang disebabkan oleh kekerasan fisik dapat berkisar dari memar ringan hingga kematian. Dalam kasus kekerasan seksual dapat menyebabkan infeksi penyakit seksual menular dan kehamilan. Dampak psikologis termasuk peningkatan kemarahan, harga diri yang rendah, kecemasan, sering ada keluhan dalam tubuh (misalnya sakit kepala), insomnia, depresi, gangguan kecemasan, posttraumatic stress disorder, gangguan makan, dan peningkatan risiko ketergantungan atau penyalahgunaan zat dan obatobatan.

Kebanyakan penelitian menunjukkan bahwa laki-laki dan perempuan sama-sama terlibat dalam kekerasan hubungan pacaran, keduanya dapat menjadi pelaku maupun korban, tetapi biasanya perempuan yang lebih menerima luka serius (Wall, 2009). Namun hal ini bertentangan dengan penelitian yang lain yang menyatakan bahwa tidak ada perbedaan gender pada kekerasan dalam pacaran (Windle \& Mrug, 2008). Laki-laki digambarkan sebagai agresif dan perempuan digambarkan sebagai pasif (Wall, 2009). Hal ini dikarenakan bahwa anak laki-laki cenderung menggunakan kekerasan fisik sebagai sarana untuk mengontrol pacar mereka, sedangkan anak perempuan lebih cenderung menggunakan kekerasan fisik untuk membela diri (Davis, 2008).

Murray (2001) menjelaskan faktor-faktor yang mempengaruhi kekerasan dalam pacaran ada beberapa faktor yang berkontribusi terhadap kekerasan dalam pacaran pada remaja, yaitu penerimaan teman sebaya, harapan peran gender, kurangnya pengalaman secara umum, jarang berhubungan dengan pihak yang lebih tua, sedikit akses ke layanan masyarakat, legalitas, dan penggunaan obat-obatan. Hal 
senada diungkapkan oleh Stewart (2010) di mana konflik keluarga, gaya pengasuhan yang otoriter, hubungan orangtua-anak, pemantauan orangtua dan kekerasan saudara kandung di dalam keluarga, dan norma-norma teman sebaya, serta keterlibatan teman sebaya berpengaruh pada kekerasan dalam berpacaran. Berdasarkan pemaparan di atas jelas sekali bahwa lingkungan dan dukungan sosial di sekitar remaja mempengaruhi kecenderungan untuk melakukan kekerasan dalam berpacaran atau tidak.

\section{Dukungan Sosial}

Menurut Ogden (2007) dukungan sosial didefinisikan dalam beberapa cara, pertama kali didefinisikan dengan jumlah teman yang individu miliki. Namun, definisi tersebut dikembangkan bahwa dukungan sosial bukan hanya dari seberapa individu memiliki jumlah teman tetapi juga kepuasan individu dengan dukungan pertemanan. Orang dengan dukungan sosial percaya mereka dicintai, dihargai, dan bagian dari jaringan sosial, seperti sebuah keluarga atau komunitas organisasi, yang dapat membantu pada saat dibutuhkan. Jadi, dukungan sosial mengacu pada tindakan yang sebenarnya dilakukan oleh orang lain, atau menerima dukungan. Tetapi ia juga merujuk kepada rasa atau persepsi bahwa kenyamanan, kepedulian, dan bantuan tersedia jika diperlukan.

Cohen dan Wills (1985) mengklasifikasikan dukungan sosial dalam lima kategori yaitu: emotional support, esteem support, tangible or instrumental support, informational support, dan network support. Kategori pertama yaitu emotional support, yang meliputi ekspresi empati, peduli, dan perhatian terhadap orang lain. Ketegori kedua yaitu esteem support, bentuk dukungan ini berupa penghargaan positif pada individu, pemberian semangat, persetujuan pada pendapat individu, dan perbandingan yang positif dengan individu lain. Bentuk dukungan ini membantu individu dalam membangun harga diri dan kompetensi. Kategori ketiga yaitu tangible or instrumental support, bentuk dukungan ini merupakan penyediaan materi yang dapat memberikan pertolongan langsung seperti pinjaman uang, pemberian barang, makanan, serta pelayanan. Bentuk dukungan ini dapat mengurangi kecemasan karena individu dapat langsung memecahkan masalahnya yang berhubungan dengan materi. Kategori keempat yaitu informational support, bentuk dukungan ini melibatkan pemberian informasi, pengetahuan, petunjuk, saran atau umpan balik tentang situasi, dan kondisi individu. Jenis informasi seperti ini dapat menolong individu untuk mengenali dan mengatasi masalah dengan lebih mudah. Kategori kelima yaitu network support, bentuk dukungan ini akan membuat individu merasa menjadi anggota dari suatu kelompok yang memiliki kesamaan minat dan aktivitas sosial dengan kelompok. Dengan begitu individu akan memiliki perasaan senasib (Sarafino \& Smith, 2002). 
Berikut ini merupakan penjelasan mengenai jenis-jenis dukungan sosial, yaitu keluarga, teman sebaya, dan seseorang yang spesial (significant others). Keluarga adalah komponen terkecil dari masyarakat. Perkembangan anak, proses sosialisasi, introjeksi nilai-nilai masyarakat, dan pembentukan superego dilakukan dalam keluarga (Sarwono, 2005). Teman sebaya merupakan hubungan antar individu yang ditandai dengan keakraban, saling percaya, menerima satu dengan yang lain, ingin berbagi perasaan, pemikiran dan pengalaman, serta kadang-kadang melakukan aktivitas bersama (Dariyo, 2004). Significant others yaitu siapa saja yang dianggap berperan penting dalam kehidupan seseorang. Canty-Mitchell dan Zimet (2000) menyatakan bahwa dimensi significant others relevan pada remaja yang pada tahap perkembangan tersebut memang sedang tertarik dengan lawan jenisnya dan mereka juga banyak dipengaruhi oleh orang dewasa yang bukan bagian dari keluarganya.

\section{METODE}

\section{Partisipan}

Sampel yang diambil dalam penelitian ini adalah 400 responden. Diketahui bahwa mayoritas partisipan dalam penelitian ini adalah perempuan, yaitu sebanyak 305 orang, dan laki-laki sebanyak 95 orang. Jika dilihat berdasarkan usianya, rentang usia partisipan dalam penelitian ini antara 15-18 tahun $(M=17, S D=1)$.

\section{Prosedur}

Peneliti menerjemahkan dua alat ukur yang akan digunakan (One way translation), setelahnya meminta pendapat dari ahli mengenai hasil penerjemahaan pada alat ukur (expert judgment), lalu menyebarkan alat ukur melalui google form dan pengambilan data langsung di SMA yang ada di Jakarta. Setelah data terkumpul dilakukan uji validitas, reliabilitas, confirmatory factor analysis, dan uji hipotesis. Adapun alat ukur dalam penelitian ini ada dua yaitu: (1) Conflict in Adolescent Dating Relationships Inventory (CADRI); dan (2) Multidimensional Scale of Perceived Social Support (MSPSS).

Alat ukur perilaku kekerasan dalam pacaran yang digunakan dalam penelitian ini adalah Conflict in Adolescent Dating Relationships Inventory (Wolfe dan kawan-kawan, 2001). CADRI yang terdiri dari perilaku kekerasan pada pelaku dan korban. Skala ini memiliki lima faktor (kekerasan fisik, 
pelecehan seksual, relasional agresi, perilaku mengacam, dan pelecehan emosional) untuk menilai korban kekerasan pacaran dan pelaku kekerasan pacaran dalam hubungan pacaran dengan 25 item. Terdapat 5 bentuk perilaku kekerasan dalam pacaran yang diukur dalam alat ini, yaitu kekerasan fisik (item 8, 25, 30, 34), kekerasan seksual (item 2, 13, 15, 19), perilaku mengancam (item 5, 29, 31, 33), agresi relasional (item 3, 20, 35), kekerasan verbal arau emosional (item 4, 7, 9, 12, 17, 21, 23, 24, 28 , 32). Lebih lanjut lagi, CADRI juga memiliki 10 item yang berisi resolusi konflik yang positif (item 1 , $6,10,11,14,16,18,22,26,27)$, namun resolusi konflik positif tidak akan digunakan dalam penelitian ini karena berdasarkan penelitian sebelumnya hal tersebut tidak terkait dengan perilaku kekerasan. Dengan kata lain, dalam penelitian ini hanya lima bentuk perilaku kekerasan dalam pacaran yang digunakan dengan 25 items.

Masing-masing item dihitung relatif terhadap perilaku responden sendiri (misalnya pelaku) dan perilaku pasangan mereka (misalnya korban) pada empat pilihan jawaban $(0=$ tidak pernah, 1 = jarang, 2 = kadang-kadang, 3 = sering). Wolfe dkk. (2001) melaporkan nilai-nilai Alpha Cronbach mulai dari.83 hingga.87 selama pengembangan awal dan validasi CADRI. CADRI telah digunakan dalam banyak studi terbaru kekerasan pacaran pada remaja (Kinsfogel \& Grych, 2004; Schiff \& Zeira, 2005). Dari hasil uji confirmatory analysis factor (CFA) diperoleh model tidak fit ( $R M S E A=.093$, $C M I N / D F=4.4, G F I=.801)$. Oleh sebab itu dilakukan modifikasi $(R M S E A=.059, C M I N / D F=2.39$, $G F I=.937)$. Koefisien Alpha Cronbach untuk CADRI dalam penelitian ini adalah.96. Alat ukur ini memiliki validitas butir berkisar dari.351 sampai dengan.657, dengan item gugur sebanyak 3 item, yaitu: item 4, 19, 23.

Sementara itu, alat ukur dukungan sosial yang digunakan dalam penelitian ini adalah The Multidimentional Scale of Perceived Social Support (Zimet, Dahlem, Zimet, \& Farley., 1998) yang terdiri dari 12 items yang mengukur sumber aspeknya, yaitu keluarga (item 3, 4, 8, dan 11), temanteman (item 6, 7, 9, dan 12), dan orang yang spesial (item 1, 2, 5, dan 10). Masing-masing aspek memiliki 4 item yang menggunakan tujuh pilihan jawaban yang meliputi, Sangat Sangat Sangat Tidak Setuju (SSTS) dengan skor 1, Sangat Tidak Setuju (STS) dengan skor 2, Agak Tidak Setuju (ATS) dengan skor 3, Netral (N) dengan skor 4, Agak Setuju (AS) dengan skor 5, Sangat Setuju (SS) denga skor 6, dan Sangat Sangat Setuju (SSS) dengan skor 7. Koefisien Alpha Cronbach untuk orang yang spesial, subskala keluarga dan teman-teman memiliki nilai.91,.87,.85 secara masing-masing. Dari hasil uji confirmatory analysis factor (CFA) diperoleh model tidak fit $(R M S E A=.1053, C M I N / D F=$ 
5.363, $G F I=.891)$. Oleh sebab itu dilakukan modifikasi $(R M S E A=.076, C M I N / D F=3.3, G F I=.943)$. Total reliabilitas seluruh skala yaitu.88. Alat ukur ini memiliki validitas butir berkisar dari.531 sampai dengan.699 dan tidak ada item yang gugur.

\section{Desain Penelitian}

Penelitian ini bersifat korelasional, berikut desain penelitian ini:

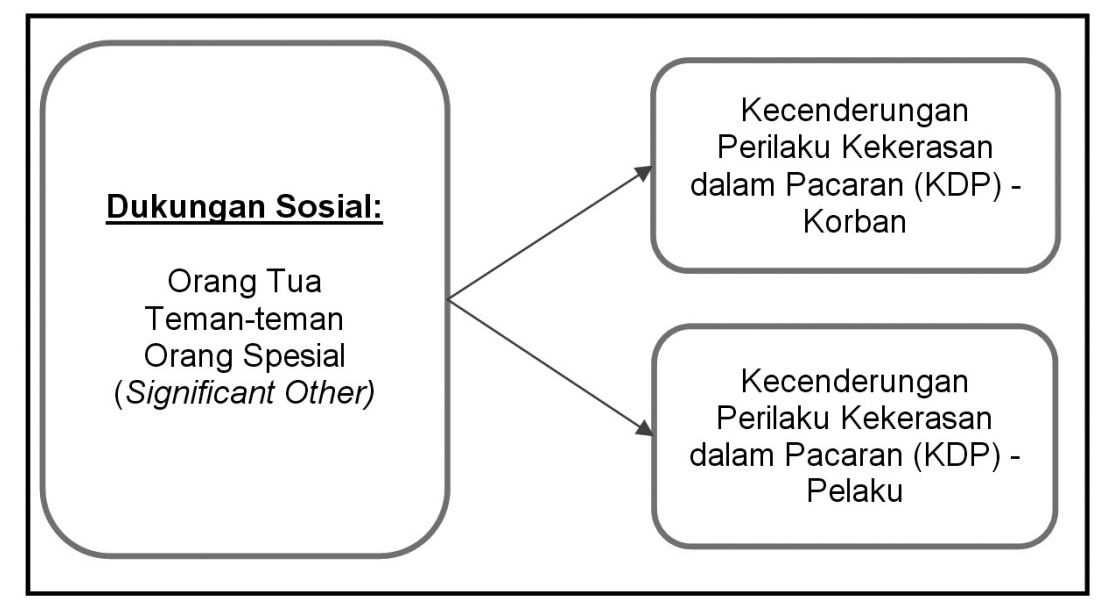

Diagram 1. Desain Penelitian

\section{Teknik Analisis}

Teknik analisis data dalam penelitian kuantitatif menggunakan uji regresi, yaitu metode statistik yang digunakan untuk mengukur besarnya sumbangan sebuah variabel.

\section{ANALISIS DAN HASIL}

\section{Gambaran Subjek}

Berikut ini adalah gambaran umum subjek penelitian berdasarkan perbedaan gender pada skor KDP (Kekerasan Dalam Pacaran) diukur dengan CADRI (Conflict in Adolescent Dating Relationships Inventory) dan Dukungan sosial diukur dengan MSPSS (Multidimentional Scale of Perceived Social Support). Tidak ada perbedaan gender pada skor KDP-Pelaku laki-laki $(M=34.5, S D=10.6)$ dan Pelaku perempuan $(M=35.4, S D=8.73), t(398)=-0.845, p=.399$. Selanjutnya, tidak ada perbedaan 
gender pada skor KDP-Korban laki-laki $(M=38.8, S D=11.8)$ dan Korban perempuan $(M=36.9, S D$ $=9.62), t(398)=1.61, p=.107$. Lebih lanjut, tidak ada perbedaan antara gender pada skor dukungan sosial pada laki-laki $(M=58.0, S D=13.1)$ dan pada perempuan $(M=62.4, S D=13.5), t(398)=-2.74$, $p=.06$. Dalam penelitian ini ditemukan ada hubungan antara KDP dan usia partisipan dengan korelasi $r(398)=.176, p<.01$.

\section{Uji Korelasi antara Dukungan Sosial dengan Perilaku Kekerasan dalam Pacaran}

Berdasarkan hasil uji korelasi ditemukan bahwa dukungan keluarga berkorelasi negatif dengan kekerasan dalam pacaran pada kategori korban $(r=-.108, p<.05)$, namun tidak pada kategori pelaku $(r=-.088, p>.05)$. Sementara itu dukungan significant others tidak berkorelasi dengan kekerasan dalam pacaran pada kategori pelaku $(r=-.065, p>.05)$, dan tidak ada hubungan antara dukungan significant others dengan kekerasan dalam pacaran pada kategori korban $(r=-.027, p>.05)$. Lebih lanjut, dukungan teman sebaya tidak memiliki hubungan dengan kekerasan dalam pacaran baik dalam kategori pelaku $(r=-.051, p>.05)$ ataupun $\operatorname{korban}(r=-.094, p>.05)$.

Tabel 1. Korelasi antara Dukungan sosial dari keluarga, teman, dan significant others terhadap kekerasan dalam pacaran pada kategori pelaku dan korban.

\begin{tabular}{|c|c|c|c|c|c|}
\hline Variabel & KDP Korban & KDP Pelaku & $\begin{array}{l}\text { Dukungan } \\
\text { Sosial } \\
\text { Significant } \\
\text { others }\end{array}$ & $\begin{array}{l}\text { Dukungan } \\
\text { Sosial } \\
\text { Keluarga }\end{array}$ & $\begin{array}{l}\text { Dukungna } \\
\text { Sosial Teman }\end{array}$ \\
\hline KDP Korban & - & & & & \\
\hline KDP Pelaku & $.664 * *$ & - & & & \\
\hline $\begin{array}{l}\text { Dukungan Sosial } \\
\text { Significat Others }\end{array}$ & -.065 & -.027 & - & & \\
\hline $\begin{array}{l}\text { Dukungan Sosial } \\
\text { Keluarga }\end{array}$ & $-.108 *$ & -.088 & $.560 * *$ & - & \\
\hline $\begin{array}{l}\text { Dukungan Sosial } \\
\text { Teman }\end{array}$ & -.051 & -.094 & $.620 * *$ & $.532 * *$ & - \\
\hline
\end{tabular}

Ket.: *Signifikan.05; ** Signifikan.01

\section{Uji Regresi antara Dukungan Sosial dengan Perilaku Kekerasan dalam Pacaran}

Berdasasarkan hasil uji regresi secara keseluruhan tidak ditemukan kontribusi dukungan sosial terhadap kecenderungan perilaku kekerasan dalam konteks sebagai pelaku $F(3,396)=2.182, p>.05$, dengan $R^{2}=.016$ ) ataupun korban dengan $F(3,396)=2.577, p>.05$, dengan $\left.R^{2}=.019\right)$. 
Namun, jika dilihat lebih mendalam ditemukan peranan keluarga dalam mencegah kekerasan dalam berpacaran dalam konteks korban sebesar $(\beta=-.132, p<.05)$, namun tidak dengan teman $(\beta$ $=.052, p>.05)$ dan juga significant others $(\beta=-.047, p>.05)$. Lebih lanjut, tidak ada pengaruh dukungan keluarga $(\beta=-.112, p>.05)$, teman $(\beta=-.064, p>.05)$, dan juga significant others $(\beta=.053, p>.05)$ terhadap kecenderungan kekerasan dalam berpacaran dalam konteks pelaku.

Tabel 2. Ringkasan Regresi Linier peranan dukungan sosial terhadap kecenderungan perilaku kekerasan dalam berpacaran dalam konteks pelaku dan korban.

\begin{tabular}{|c|c|c|c|c|c|c|}
\hline \multirow{2}{*}{ Variabel } & \multicolumn{3}{|c|}{ Korban } & \multicolumn{3}{|c|}{ Pelaku } \\
\hline & $B$ & $S E B$ & $\beta$ & $B$ & $S E B$ & $\mathbf{B}$ \\
\hline Keluarga & -.220 & .104 & $-.132 *$ & -.175 & .098 & -.112 \\
\hline Teman & .103 & .131 & .052 & -.120 & .124 & -.064 \\
\hline Significant Others & -.088 & .125 & -.047 & .092 & .118 & .053 \\
\hline$R^{2}$ & & .019 & & & .016 & \\
\hline $\mathrm{F}$ & & 2.577 & & & 2.182 & \\
\hline
\end{tabular}

Ket.: *Signifikan.05; ** Signifikan.01

\section{DISKUSI}

Penelitian ini bertujuan untuk melanjutkan penelitian sebelumnya yang ditemukan bahwa dukungan dari keluarga dan teman berpengaruh terhadap kecenderungan seseorang untuk melakukan atau menjadi korban kekerasan dalam berpacaran. Sejauh yang peneliti sebelumnya ketahui, belum ada penelitian yang menunjukkan bagaimana hubungan orang yang spesial terhadap kecenderungan kekerasan dalam berpacaran. Oleh sebab itu, peneliti mengeksplorasi lebih jauh tentang dukungan dari orang yang spesial terhadap kecenderungan kekerasan dalam berpacaran baik itu dari sisi korban dan pelaku.

Setelah dilakukan analisa data didapatkan hasil bahwa: pertama, terdapat hubungan antara dukungan keluarga terhadap KDP pada kategori korban $(r=-.108, p<.05)$ namun tidak pada kategori pelaku $(r=-.088, p>.05)$. Hasil ini mendukung hasil penelitian sebelumnya yang menjelaskan bahwa anak-anak yang memiliki hubungan yang kacau dengan orangtua akan melihat sebuah hubungan sebagai sumber kekecewaan dan mereka akan memiliki pandangan negatif mengenai peran mereka dalam sebuah hubungan, sehingga membuat mereka akan mudah menjadi korban (Leadbeater dan kawan-kawan., 2008). Lebih lanjut, hasil yang hampir sama ditemukan pada penelitian Nelson dan 
Crick (2002) yang menjelaskan bahwa perilaku orangtua dengan kontrol psikologi yang tinggi dan over-protective menyebabkan anak cenderung menjadi korban dan melakukan agresi relasional. Leadbeater dan kawan-kawan. (2008) menjelaskan dalam penelitiannya bahwa responden yang melaporkan tingkat pengendalian psikologis ibu yang lebih tinggi dan pemantauan yang lebih rendah cenderung menggunakan agresi relasional dalam hubungan pacaran mereka. Hal ini dikarenakan anak mencontoh perilaku orangtua yang menggunakan kontrol psikologis yang biasanya juga melakukan manipulasi sebagai sarana untuk mengontrol hubungan dekat (close relationship). Dari kedua penelitian di atas dapat diambil kesimpulan bahwa peranan orangtua sangat besar bagi anak terutama ketika anak menjalin relasi dengan teman dan lingkungannya.

Kedua, tidak terdapat hubungan antara dukungan sosial dari teman sebaya terhadap terhadap KDP pada kategori pelaku $(r=-.051, p>.05)$ ataupun korban $(r=-.094, p>.05)$. Hal ini dikarenakan pengetahuan teman sebaya dalam mengidentifikasikan tanda-tanda kekerasan dalam pacaran masih sangat terbatas (Richards \& Branch, 2012). Hal ini bertentangan dengan penelitian yang dilakukan oleh Brendgen, Vitaro, Doyle, Markiewicz, dan Bukowski (2002) di mana telah dijelaskan bahwa anakanak yang memiliki sejarah bermasalah sesama rekan interaksi cenderung untuk mentransfer pola-pola maladaptive mereka pada hubungan pacaran. Sebagai contoh, teman-teman yang menyetujui atau terlibat dalam tindakan agresif dan kekerasan hubungan pacaran lebih mungkin untuk mengikutinya daripada rekan-rekan yang menolak perilaku agresif dan kekerasan dalam pacaran pada remaja. Lebih lanjut, terdapat jenis pertemanan di mana agresi dalam hubungan berpacaran lebih dianggap sesuatu yang wajar sehingga membuat mereka lebih agresif ketika berpacaran (Kinsfogel \& Grych, 2004). Penelitian yang hampir sama juga membuktikan bahwa dukungan teman sebaya berhubungan erat dan berpengaruh lebih besar untuk menurunkan tingkat kekerasan dalam pacaran pada remaja dibandingkan dengan dukungan dari orangtua (Richards dan kawan-kawan., 2014). Oleh karenanya, penelitian ini masih membutuhkan kajian lebih lanjut mengenai dinamika peranan teman dalam membentuk dan mengembangkan kekerasan dalam pacaran.

Ketiga, tidak terdapat hubungan antara dukungan sosial dari orang yang spesial (significant others) dengan perilaku kekerasan dalam pacaran baik dalam kategori pelaku $(r=-.065, p>.05)$ dan korban $(r=-.027, p>.05)$. Orang spesial dalam hal ini adalah seseorang yang memiliki pengaruh pada kehidupan seseorang yang tidak berasal dari kerabat ataupun sahabat individu tersebut. Untuk remaja sendiri, artis idola merupakan salah satu contoh significant others yang mempengaruhi kehidupan remaja. Dalam beberapa penelitian, orang yang spesial (significant others) memiliki pengaruh penting 
bagi perkembangan remaja, seperti contohnya riset yang dilakukan oleh Jang, Sung, Park, dan Jeon (2016) mengenai meningkatnya angka bunuh diri pada orang di Korea Selatan sebagai bentuk copycat atau perilaku meniru dari perilaku bunuh diri di kalangan selebriti. Hal ini dikarenakan penggemar mengidentifikasikan dirinya dengan figur yang mereka idolakan, sehingga semakin sedikit seseorang mengidentifikasikan dirinya dengan idola mereka maka semakin kecil kecenderungan mereka untuk meniru perilaku tersebut. Namun, dalam penelitian ini tidak ditemukan adanya korelasi antara dukungan sosial dari orang spesial (significant others) dengan kecenderungan perilaku kekerasan pada remaja. Hal ini perlu diteliti lebih lanjut karena semakin maraknya dating violence dilakukan oleh remaja setiap harinya.

\section{SIMPULAN DAN SARAN}

\section{Simpulan}

Dari hasil penelitian ini ditemukan bahwa peranan keluarga sangat berkorelasi terhadap kecenderungan seseorang untuk melakukan perilaku kekerasan dalam berpacaran, namun tidak dengan teman sebaya dan significant others. Hal ini menunjukkan besarnya pengaruh dukungan dari keluarga terutama orangtua anak dalam membangun interaksi dengan lawan jenis yang lebih sehat dan konstruktif. Dalam penelitian ini significant others tidak memiliki korelasi dengan kecenderungan perilaku kekerasan dalam berpacaran. Hal ini mungkin dikarenakan oleh significant others bukanlah seseorang yang memiliki dampak langsung dalam kehidupan remaja pada penelitian ini. Lebih lanjut, dukungan dari sebaya juga tidak berkorelasi dengan KDP mungkin dikarenakan kurangnya kelekatan di antara mereka, sehingga dukungan dari keluarga yang sangat berkorelasi terhadap kecenderungan remaja untuk melakukan maupun menjadi korban perilaku kekerasan dalam berpacaran.

\section{Saran Teoritis}

Bedasarkan hasil penelitian yang diperoleh, peneliti menyarankan beberapa hal untuk penelitian selanjutnya, yaitu sebagai berikut: (1) untuk mengidentifikasi siapa significant others atau orang yang spesial, yang memberikan kontribusi dalam kesehariannya dan mengukur seberapa besar individu tersebut mengidentifikasikan dirinya dengan significant others tersebut dan (2) untuk melakukan penelitian dengan pendekatan kualitatif agar hasil yang diperoleh lebih maksimal dalam menggambarkan peranan masing-masing orang dalam kehidupan remaja. 


\section{Saran Praktis}

Diharapkan bahwa orangtua maupun para pembimbing sebagai motor penggerak generasi muda diharapkan lebih memperhatikan keadaan yang dialami oleh remaja-remaja yang mengalami kekerasan dalam pacaran, baik yang melakukan maupun yang menjadi korban. Lebih lanjut, orangtua juga diharapkan agar lebih mengedukasi anak remajanya mengenai perkembangan seksualitas remaja yang sehat sehingga tidak terlibat pada kekerasan dalam pacaran. Hasil penelitian ini juga dapat berguna bagi remaja sendiri untuk mengevaluasi diri agar tidak terjebak pada hubungan yang bernuasa kekerasan dan memiliki sikap tegas untuk menghindari kekerasan dalam pacaran baik menjadi pelaku maupun korbannya.

\section{REFERENSI}

Brendgen, M., Vitaro, F., Doyle, A. B., Markiewicz, D., \& Bukowski, W.M. (2002). Same-sex peer relations and romantic relationships during early adolescence: Interactive links to emotional, behavioral, and academic adjustment. Merrill-Palmer Quarterly, 48, 77-103.

Canthy-Mitchell, J., \& Zimet, G. D. (2000) Psychometric Properties of multidimensional scale of perceived social support in urban adolescents. American Journal of community psychology, 28 (3), 391-400. doi: 10.1023/A: 1005109522457

Cohen, S., \& Wills, T. A. (1985). Stress, social support and the buffering hypothesis. Psychological Bulletin, 98, 310-357.

Dariyo, A. (2004). Psikologi perkembangan remaja. Bogor: Ghalia Indonesia.

Davis, A. (2008). Interpersonal and Physical Dating Violence among Teens. Views from the National Council on Crime and Delinquency. Ditemu kembali dari http://www.nccdglobal.org/sites/ default/files/publication_pdf/focus-dating-violence.pdf

Jang, S. A., Sung, M. J., Park, Y. J., \& Jeon, T. W. (2016). Copycat suicide induced by entertainment celebrity suicides in South Korea. Korean Neuropsychiatric Association, 13(1), 74-81. doi: http:// dx.doi.org/10.4306/pi.2016.13.1.74

Kinsfogel, K. M., Grych, J. H. (2004). Interparental conflict and adolescent dating relationships: Integrating cognitive, emotional, and peer influences. Journal of Family Psychology, 18(3), 505-515. 
Lamm, T. N. (2010). Examining dating violence in adolescent relationships and prevention program options for educators (Tesis tidak dipublikasikan). University of Wisconsin-Stout, Amerika Serikat.

Leadbeater, B. J., Banister, E. M., Ellis, W. E., \& Yeung, R. (2008). Victimization and relational aggression in adolescent romantic relationships: The influence of parental and peer behaviors, and individual adjustment. Journal Youth Adolescence, 37, 359-372. doi: 10.1007/s10964-007-9269-0

Murray, J. (2001). But I love him; protecting your teen daughter from controlling, abusive dating relationships. New York, NY: Harper Collins.

Nelson, D. A., \& Crick, N. R. (2002). Parental psychological control: Implications for childhood physical and relational aggression. In B. K. Barber (Ed.), Intrusive parenting: How psychological control affects children and adolescents (pp. 161-189). Washington, DC: American Psychological Association.

Nurrakhmi, M, \& Astuti, Y. D. (2008). Hubungan antara kepribadian ekstrovert dengan kecenderungan melakukan kekerasan dalam pacaran. Universitas Islam Indonesia Yogyakarta. Ditemu kembali dari http://psychology.uii.ac.id/images/stories/jadwal_kuliah/naskah-publikasi-04320166.pdf

Ogden, J. (2007). Health psychology: A textbook (4th ed.). New York, NY: McGraw-Hill.

Payne, K. L., Ward, T., Miller, A., \& Vasquez, K. (2013). Teen Dating Violence: A Resource and Prevention Toolkit. Alverno College Research Center for Women and Girls. Retrived from: https://www.alverno.edu/media/alvernocollege/rcwg/pdfs/TeenDatingToolkit.pdf

Richards, T. N., \& Branch, K. A., (2012). The relationship between social support and adolescent dating violence: A comparison across genders. Journal of Interpersonal violence. 27(8), 1540-1561. doi: 10.1177/0886260511425796

Richards, T. N., Branch, K. A., \& Ray, K. (2014). The impact of parental and peer social support on dating violence perpetration and victimization among female adolescents: A longitudinal study. Violence and Victims, 29(2), 317-331

Sarafino, E. P., \& Smith, T. W. (2002). Health psychology biopsychosocial interaction (4th Ed.). New York, NY: John Wiley \& Sons.

Sarwono, S. W. (2005). Teori-teori psikologi sosial. Jakarta, Indonesia: PT Raja Grafindo Persada. 
Schiff, M., \& Zeira, A. (2005). Dating violence and sexual risk behaviors in a sample of at-risk Israeli youth. Child Abuse \& Neglect,29, 1249-1263.

Stewart, B. T. (2010). The moderating effect of perceived positive peer norms on the relationship between age, gender, acceptance of violence, and perpetration of teen relationship violence (Tesis tidak dipublikasikan). San Diego State University, Amerika Serikat.

Wall, A. (2009). Relationship violence: Risk factors for adolescents. Journal of Undergraduate Research at Minnesota State University, 9(17), ditemu kembali dari http://cornerstone.lib.mnsu.edu/jur/ vol9/iss1/17

Windle, M., \& Mrug, S. (2008). Cross-gender violence perpetration and victimization among early adolescents and associations with attitudes toward dating conflict. Journal Youth Adolescence, 38, 429-439. doi: 10.1007/s10964-008-9328-1.

Wolfe, D. A., Wekerle, C., Scott, K., Straatman, A., Grasley, C., \& Reitzel-Jaffe, D. (2001). Development and validation of the conflict in adolescent dating relationships inventory. Psychological Assessment, 13(2), 277-293.

Zimet, G. D., Dahlem, N. W., Zimet, S. G., \& Farley, G. K. (1998). The multidimensional scale of perceived social support. Journal of Personality Assessment, 52, 30-41. 